\title{
Quality of different brands of metronidazole available in jimma town, south west Ethiopia; A cross- sectional pharmaceutical quality study
}

\author{
Teshome Sosengo, ${ }^{1}$ Tesfaye Mohammed, ${ }^{2}$ Ramanjireddy Tatiparthi ${ }^{2}$ \\ ${ }^{1}$ School of Pharmacy, College of Health and Medical Sciences, Haramaya University, Ethiopia \\ (teshomesosengo@gmail.com) \\ ${ }^{2}$ School of Pharmacy, Institute of Health Sciences, Jimma University, Ethiopia
}

\begin{abstract}
Received Accepted

30.11.2020 31.12.2020
\end{abstract}

Background: WHO report of 2017 estimates that the rates of substandard and falsified medical products in low- and middle-income countries is approximately $10.5 \%$ with an estimated spend of US\$ 30.5 billion.

Objective: The purpose of the study is to assess the quality of different brands of metronidazole available in Jimma town, Oromia region, South West Ethiopia.

Methods: Cross-sectional study was conducted in Jimma town, Oromia regional state, Ethiopia. The study was conducted from May 03 - July 30, 2018. Samples were collected using convenience sampling technique. The samples were analyzed using methods specified in British Pharmacopoeia 2013 and United States Pharmacopoeia 2015.

Results: All the seven brands of Metronidazole analyzed for quality passed identity test specification of BP 2013. The three brands of Metronidazole capsules passed weight uniformity and dissolution test specification of USP 2015. The seven brands of Metronidazole passed assay (i.e. drug content) test specification of USP 2015. The highest percentage of drug content, $107.81 \%$ and $105.56 \%$, obtained for Metronidazole (generic)(capsule) and Nirmet(injection) respectively. However, statistical comparison of assay of respective brands of the respective 
dosage forms at $95 \%$ confidence interval indicates that there exists significant difference in assay within and among the brands of the respective dosage forms $(p<0.05)$. All the four brands of Metronidazole injections passed USP 2015 limit for Endotoxin, Endotoxin limit $<0.35 \mathrm{Eu} / \mathrm{ml}$. Two brands of Metronidazole injection, Aldezol and Metris, failed sterility test from the four brands of Metronidazole injections included in the study and hence of poor quality.

Key words: Counterfeit drugs, falsified drugs, poor quality drugs, quality, substandard drugs جودة الماركات المختلفة من الميترونيدازول المتوفرة في جيماتاون ( اثيوبيا) دراسة الجودة الصيدلانية الثاملة الملخص

المقدمة: يقدر تقرير منظمة الصحة العالمية ( WHO ) لعام 2017 ان معدلات المنتجات الطبية المتدنية

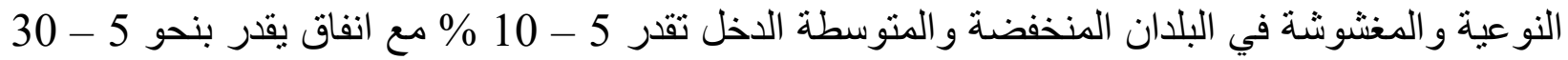
مليار دولار تقريبا.

الهدف: الغرض من الدراسة هو تقييم جودة الادوبة التجارية المختلفة للميترونبدازول المتوفر في جيما، منطقة أوروميا، جنوب غرب الثن الثيوبيا.

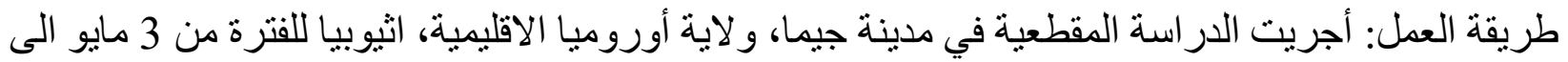

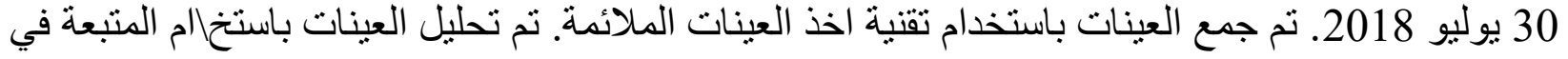
دستوري الادوية البريطاني 2013 ودستور الادوية الامريكي 2015.

النتائج: جميع الادوية التجارية السبعة للميتدونيدازول التى تم تحليلها من اجل جودة الدواء ومطابقتها

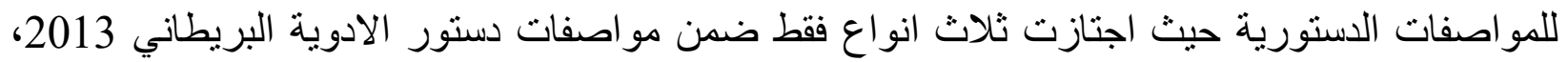

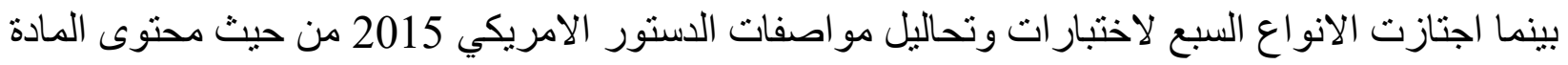

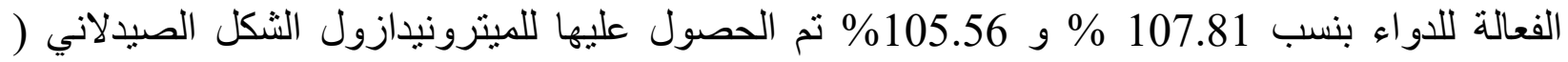

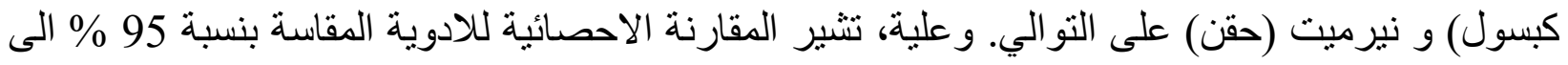

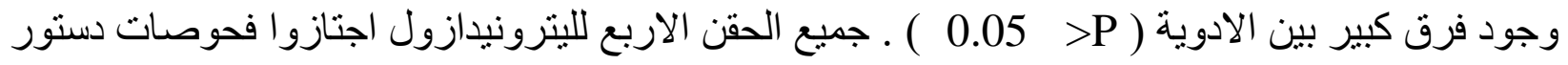

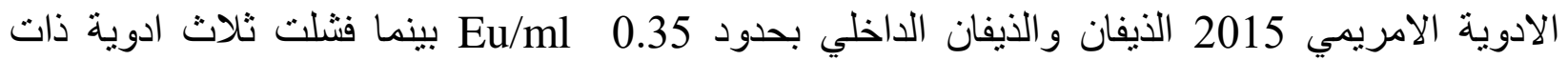
العلامات التجارية للحقن نيترو انبدازول، الديزول وميترز وذات جودة ردئية غير صالحة للاستخدام.

\section{INTRODUCTION}




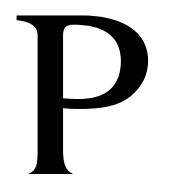

oor quality medicines include substandard and falsified (i.e. counterfeited) medicines. Substandard medical products are authorized medical products that fail to meet either their quality standards or their specifications or both. Poor quality drugs are worldwide problem with high prevalence in low and middle income countries. WHO report of 2017 estimates that the rates of substandard and falsified medical products in low- and middle-income countries is approximately $10.5 \%$ with an estimated spend of US\$ 30.5 billion(1,2).

WHO global surveillance and monitoring system for substandard and falsified medicines has received more than 1500 reports of substandard or falsified medicines, with $42 \%$ of reports coming from sub-Saharan Africa, and $21 \%$ each coming from the Americas and Europe in the years from 2013-2017. During the years, $8 \%$ of reports came from the Western Pacific, 6\% from the Eastern Mediterranean and 2\% from SouthEast Asia(1). The problem of poor quality medicines affects almost all categories of drugs (3) Antibiotics and anti-malarias are most commonly reported poor quality drugs (4). Systematic literature review of substandard and counterfeit medicines performed on 15 studies report out that $28.5 \%$ of the samples included in the studies were of poor quality. In the study, antibiotics being the most commonly reported poor quality drugs followed by anti-malarial drugs (2).

Poor quality pharmaceuticals frequently fail to meet critical quality attributes specification limit set for them when tested for quality. Failure to comply with API, dissolution and disintegration specification is most commonly reported problems in poor quality pharmaceuticals $(2,5,6)$. A retrospective quality assessment study done in Canada on 653 defective drugs report out that 205(32\%) of the products have low concentrations of active ingredients, impurities, dissolution and disintegration failures (2). In August 2013, Ghana seized 64 000 doses of falsified anti-malaria medicines that when tested found to contain only $2 \%$ of API (1).

In Sub-Saharan Africa an estimated 400,000 children are exposed to malaria are treated with poor quality anti-malaria medicines (7). Treatment of patients with poor quality pharmaceuticals causes deleterious problems as treatment failure, increased morbidity and mortality, 
wastage of budget of family and government and emergence of drug resistance $(8,9,10,11)$.

Metronidazole is [1-(2 hydroxyethyl)2-methyl-5-nitroimidazole] BCS class I drug that was discovered in the 1960s (Rediguieri et al., 2011). Since from its discovery, it is used in treatment of numerous infections caused by bacteroides, clostridia, helicobacter, trichomonas, giardia and entamoeba, dental infections, skin infections, surgical prophylaxis and antibiotic associated pseudomembraneous colitis $(12,13$, 14). The chemical structure is shown below in figure 1 . In spite of its broad use, poor quality Metronidazole has been frequently reported $(15,16)$.

Systematic literature review done in Japan on 86 studies found out that metronidazole was the second most repeatedly reported substandard antibiotic next to cloxacillin and from the 277 samples of metronidazole included in the literature review, $69(24.9 \%)$ of the metronidazole samples were substandard(17). Treatment with substandard dose of metronidazole causes emergence of drug resistance and treatment failure $(18,19)$.

In Ethiopia, except a few attempt of certain scholars to assess quality of certain drugs circulating on the pharmaceutical market of the country, the quality status of majority of the drugs circulating in the health care system of the country yet remain unknown. Therefore, this study assessed the quality of different brands of metronidazole marketed in Jimma town

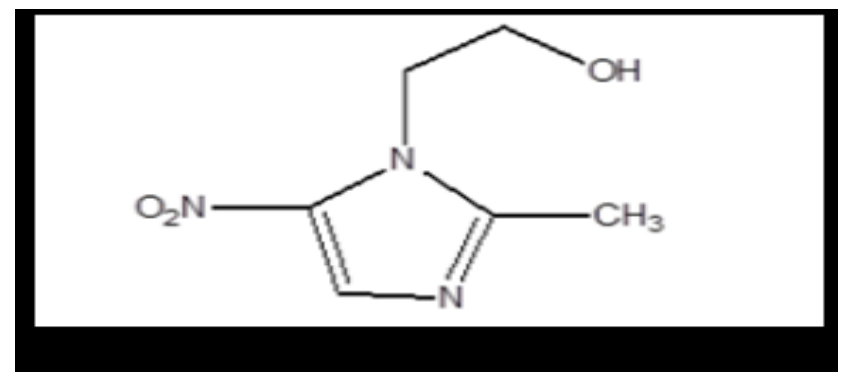

A) Metronidazole

Figure 1: Chemical structure of Metronidazole 


\section{METHODS AND MATERIALS}

\section{METHODS}

\section{Study area and period}

The study was conducted in Jimma town, Oromia regional state, Ethiopia. It is located $352 \mathrm{~km}$ South West of Addis Ababa. Currently in Jimma town there exits 33 drug stores and 22 pharmacies serving the population. The study was conducted from May 03 - July 30, 2018.

\section{Study design}

A cross sectional study was conducted to determine quality of Metronidazole available in Jimma town.

\section{Sample collection technique}

Samples were collected using convenience sampling technique (20). Detailed information of the samples purchased for analysis of quality on the present study is indicated in tables 1 and 2.

Table 1: Detailed information on Metronidazole $250 \mathrm{mg}$ capsule analyzed for quality.

\begin{tabular}{|l|l|l|l|l|l|}
\hline Manufacturer & Brand name & Strength & Batch No & Mfg.date & Exp.date \\
\hline $\begin{array}{l}\text { EPHARM. Ltd., } \\
\text { Ethiopia }\end{array}$ & $\begin{array}{l}\text { Metronidazole } \\
\text { (generic) }\end{array}$ & $250 \mathrm{mg}$ & BN712018 & $07 / 2017$ & $12 / 2021$ \\
\hline $\begin{array}{l}\text { Cadila Pharmaceuticals } \\
\text { Plc, India }\end{array}$ & Camezol & $250 \mathrm{mg}$ & D17062bx56 & $12 / 2017$ & $11 / 2020$ \\
\hline $\begin{array}{l}\text { Addis Pharmaceuticals } \\
\text { Factory Plc, Ethiopia }\end{array}$ & Metazol & $250 \mathrm{mg}$ & BN23336 & - & $06 / 21$ \\
\hline
\end{tabular}

Table 2: Detailed information on Metronidazole injections analyzed for quality.

\begin{tabular}{|l|l|l|l|l|l|}
\hline Manufacturer & $\begin{array}{l}\text { Brand } \\
\text { Name }\end{array}$ & Strength & Batch № & Mfg.date & Exp.date \\
\hline $\begin{array}{l}\text { Aculife Health care } \\
\text { Pvt.Ltd., India }\end{array}$ & Nirmet & $500 \mathrm{mg} / 100 \mathrm{ml}$ & $2 \mathrm{H} 61981$ & Aug.2016 & Jul.2019 \\
\hline $\begin{array}{l}\text { Unique Pharmaceuticals } \\
\text { Labs., India }\end{array}$ & Metrogyl & $500 \mathrm{mg} / 100 \mathrm{ml}$ & Plx7070 & $04 / 2017$ & $03 / 2020$ \\
\hline Albert David Ltd., India & Aldezol & $500 \mathrm{mg} / 100 \mathrm{ml}$ & P6130023E & $06 / 2016$ & $05 / 2019$ \\
\hline
\end{tabular}




\begin{tabular}{|l|l|l|l|l|l|}
\hline Claris Otsuka Pvt., India & Metris & $500 \mathrm{mg} / 100 \mathrm{ml}$ & C262629 & $10 / 2016$ & $09 / 2019$ \\
\hline
\end{tabular}

\section{Quality Assurance}

Sample collectors (i.e.mystery shoppers) were trained for 1 day. The training was given on allocation of pharmacies and drug stores for sample collection and how to purchase enough samples to allow for quality assessment (20). Then, the samples were brought to Ethiopian pharmaceutical manufacturing

company (EPHARM) quality control laboratory next day to the day of completion of sample collection for analysis. To ensure reliability of results, calibrated and validated equipments was used for all procedures and relevant standard operating procedures (SOPs) was followed for all tests during the laboratory analysis of the samples.

\section{Operational definitions}

Assay: Content of active pharmaceutical ingredient.

Biopharmaceutical classification system I (BCSI) drugs: Drugs that have high permeability and high solubility and rate limiting step for

\section{Data Analysis}

The assay result of all the seven brands of metronidazole and dissolution test result of the three brands of metronidazole capsules was entered to statistical package for social sciences software version 24.0 for windows. Then, one way analysis of variance (ANOVA) was performed using Tukey test to determine whether there exists significant difference in assay and dissolution test results within and among the brands of the respective dosage forms $(\mathrm{p}<0.05)$.

\section{Ethical Approval}

The study was reviewed and approved by the ethical review committee of Jimma University, Institute of Health.

absorption to systemic circulation is dissolution of the drug.

Contamination: The undesired introduction microbes to a pharmaceutical dosage form above tolerance limit tolerable in official compendias. 
Identity: Presence of specified active ingredient.

Poor quality: Drugs that fail to meet quality specification set for them.

Specification: Set of criteria to which a drug product should conform to be considered acceptable for its intended use.

Stability of medicines: The ability of the medicines to maintain the physical, chemical, and microbial properties during the time of storage and usage by the patient.

\section{Materials}

\section{Equipment}

FTIR 8400S (SHIMADZU, Japan), HPLC(Japan), dissolution tester (India), UV-

Spectrophotometer(Shmadzu/Japan), evaporating dish(Britain), sonicator(Bandelin/Germany), thermometer(Frankfurt/Germany),

Metronidazole ICRS (Lot number: 183118, WHO center for chemical reference substances, Sweden) was obtained from EPHARM. volumetric flask(England), pycnometer(Germany), Whatman GFC paper(England), conical flask(MERK /Germany), $0.45 \mu \mathrm{m}$ Nylon membrane filter(Germany), analytical balance(METLER TOLEDO, Switzerland), pH(Metler Toledo, China), incubator (SANYO, Japan), heating oven(Eclipse, Italy), and $\mathrm{KBr}$ (Britain).

\section{Solvents/Chemicals/Reagents}

Methanol(CARLOERBA/France), 1 $\mathrm{M}$ phosphoric acid(Germany), $0.1 \mathrm{~N}$ $\mathrm{HCl}($ Schlau/Spain), Nacl(Fischer scientific/UK), monobasic potassium phosphate(CARLOERBA/France), thioglycolate medium(Himedia laboratory Pvt.Ltd/India), Isopropyl alcohol (National Alcohol/Ethiopia), acetone(CARLOE RBA/France), LAL reagent(Charles River/India), TSA(Sisco reasercher Laboratory/India), Water for bacterial endotoxin test (Nearlite/India), Endotoxin reagent (Charles reagent/India),distilledwater(EPHAR M/Ethiopia). 


\section{TESTS}

\section{Identification tests}

Identification Test of Metronidazole

Capsules: Metronidazole capsules identification test was carried out according to a method specified in British Pharmacopoeia (BP) 2013. First, the content of 10 capsules was mixed. Then, $10 \mathrm{mg}$ of Metronidazole sample was taken in potassium Bromide plate( $\mathrm{KBr}$ ) plate to the fourier transform infrared spectroscopy (FTIR) instrument for the identification test (BP, 2013).

\section{Identification} Metronidazole

Identification test for Metronidazole injections was done based on BP 2013. First, $20 \mathrm{ml}$ of Metronidazole injection and $9 \mathrm{~g} \mathrm{NaCl}$ was collected in separatory funnel and shacked for 5 minutes (20). Then, $20 \mathrm{ml}$ of acetone was added to it and the mixture was allowed to separate. The upper layer was evaporated to dryness in an evaporating dish and $10 \mathrm{mg}$ of the sample was taken in $\mathrm{KBr}$ plate to FTIR instrument for the identification test (21).

\section{Weight uniformity test}

Weight uniformity test was as per a method specified in United States
Pharmacopeia (22). First, 10 capsules were selected randomly (22). Then, each intact capsule was weighed and its shell was opened and its content removed. The empty shell was weighed and the net weight of the content of the each capsule was determined by subtracting the weight of the shells from the weight of the intact capsule. The procedure was repeated for the remaining 9 capsules.

\section{Dissolution test}

Dissolution test for Metronidazole capsules was performed using a USP Apparatus I (22). The paddle was set at $100 \mathrm{rpm}$ and $900 \mathrm{ml}$ dissolution $0.1 \mathrm{~N} \mathrm{HCl}$ was used to test all samples. Prior to dissolution testing, the dissolution media was preheated and degassed. Dissolution testing was started after the temperature of $37^{\circ} \mathrm{C} \pm 0.5^{\circ} \mathrm{C}$ was confirmed in all six vessels. In pre-set time points of 10 , $15,20,30,45$ and 60 minutes, $5 \mathrm{ml}$ of the sample solution was taken with syringe from the dissolution vessel and filtered through $0.45 \mu \mathrm{m}$ membrane filter. Then, the first $2 \mathrm{ml}$ was discarded and the remaining $3 \mathrm{ml}$ of the filtrate was transferred to $50 \mathrm{ml}$ volumetric flask and diluted to a volume with $0.1 \mathrm{~N} \mathrm{HCl}(22)$. Then, 1.5 $\mathrm{ml}$ the sample solution was placed in Quartz cuvets and put in to UV 
spectrophotometer and its reading was recorded.

\section{Assay tests}

Assay test for Metronidazole capsules: Assay test was done using a method specified in USP 2015(22).

Assay test for Metronidazole injections: Assay test was done using a method specified in USP 2015(22).

\section{Microbiological tests}

\section{Endotoxin test}

Endotoxin test was done according to a method specified in USP 2015. The sample solution was prepared by mixing $0.1 \mathrm{ml}$ of the sample stock solution and $0.1 \mathrm{ml}$ of LAL solution and stored at $37^{\circ} \mathrm{C}$ for 1 hour(22).

\section{RESULT S AND DISCUSSION}

\section{Identification test results}

The identification test for all the seven brands was performed according to a method indicated in BP 2013 for identification of the drug. The IR spectrums of the standard (i.e. Metronidazole ICRS) and the samples are coinciding, indicating the standard and the seven brands of

\section{Sterility test}

Sterility test was done based on a method indicated on USP 2015. The exterior of all product primary containers was cleansed with $70 \%$ isopropyl alcohol and allowed to completely dry. Then, the samples were taken to the working area and all the contents of the bottles were aseptically filtered through a two $0.45 \mu \mathrm{m}$ membrane filters. The filters was rinsed with five $10 \mathrm{ml}$ of distilled water. Finally, to each membrane filter, each $100 \mathrm{ml}$ of tryptone soya broth and thioglycolate medium was transferred and incubated for 14 days at $22^{\circ} \mathrm{C}$ and $32{ }^{\circ} \mathrm{C}$ respectively (22).

Metronidazole analyzed on the present study have similar IR spectrum absorption frequency, which in turn shows identity of API of interest in the samples (Figure 1 and 2 ). Accordingly, all the brands passed the test for identification test. Identification tests performed on Metronidazole in various countries demonstrate mixed results. As in the present study, all the brands analyzed passed an identity test in a study done at Addis Ababa, Ethiopia (23) and 
Zaria, Nigeria (24). In contrary to this study finding, in a study done in Nigeria on 581 drugs, in which the 36 of the samples are Metronidazole tablets and 5 of samples are Metronidazole suspensions, all the Metronidazole suspensions included in the study failed identification test (15). A possible reason that the samples failed an identity test may be the samples of Metronidazole suspensions analyzed on the study were falsified (counterfeited). Treatment with medicines void of active ingredient by failing to suppress infection, leads to build up of pathogens, progression of underlying disease and engenders the development of drug resistance.

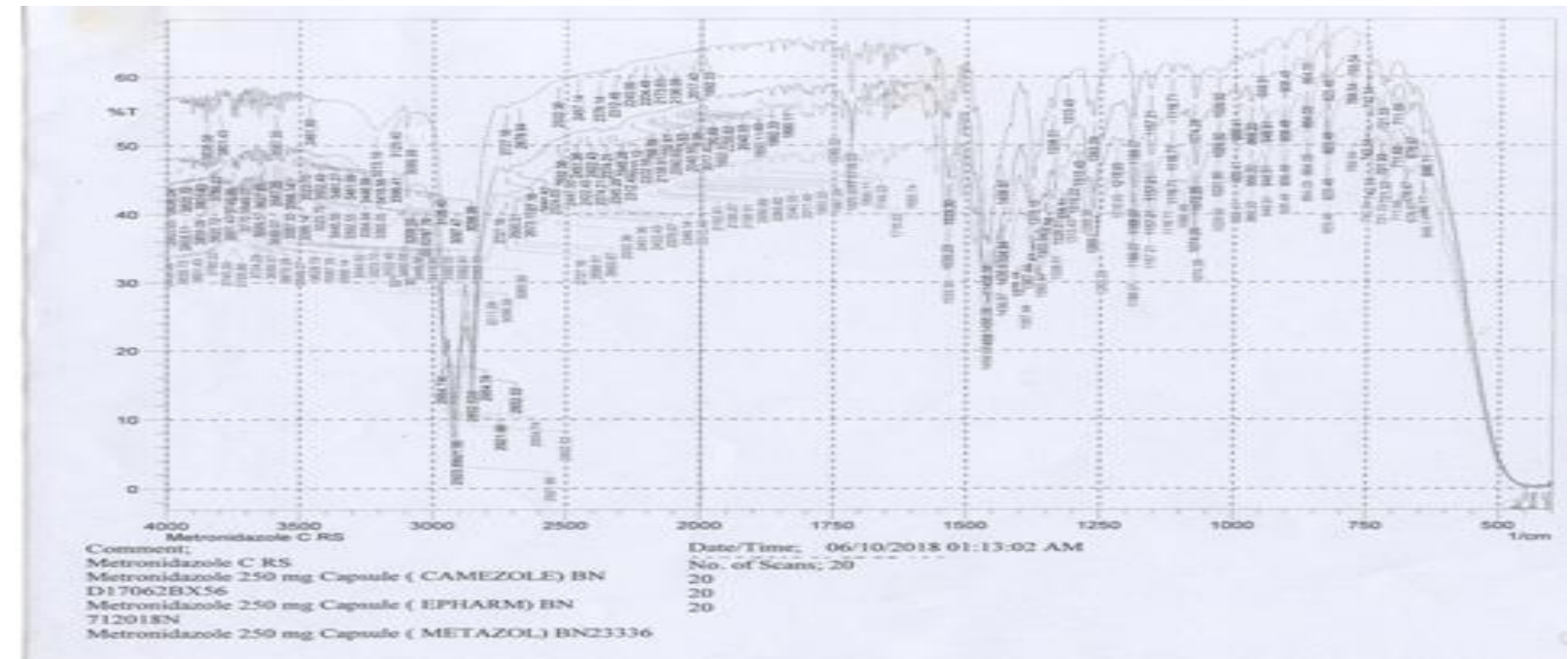

Figure 2: Merged FTIR spectrum of three brands metronidazole capsules and metronidazole ICRS.

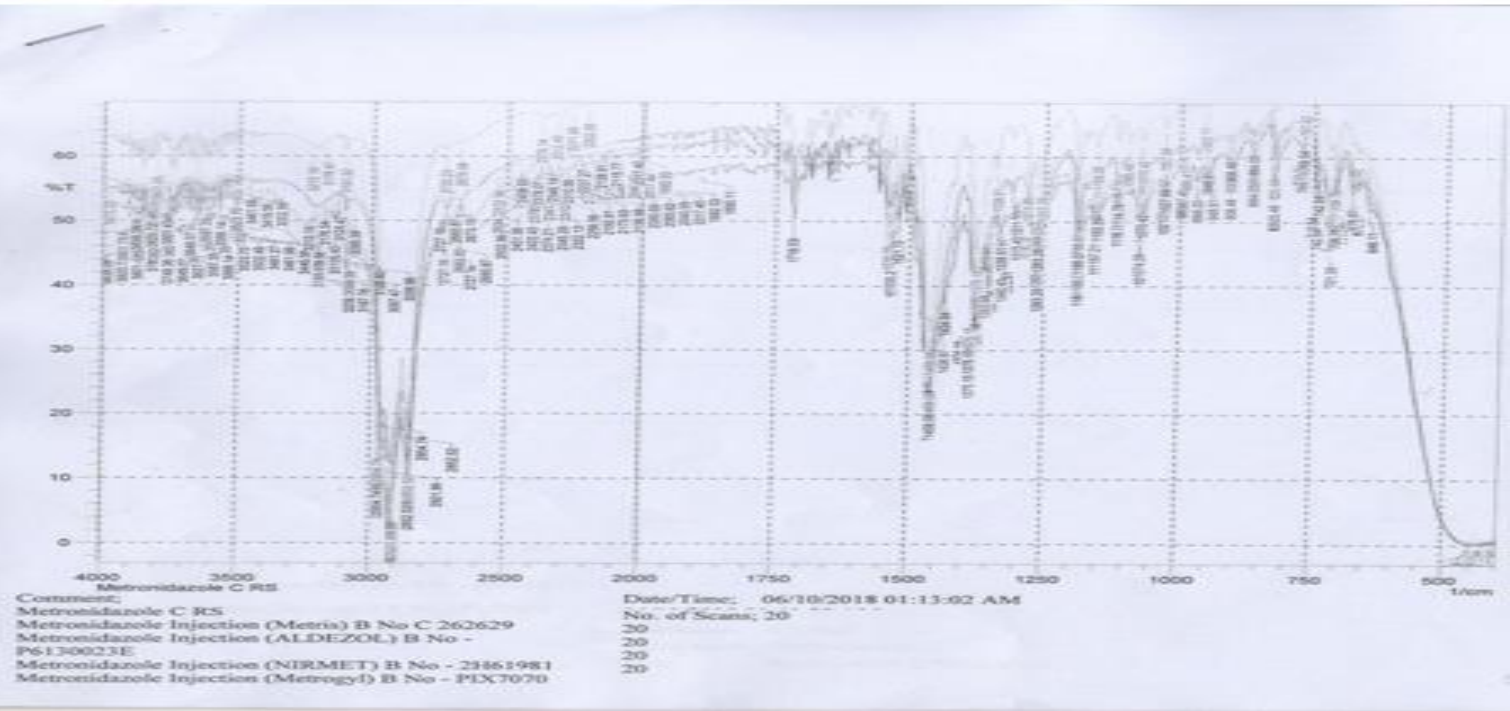


Figure 3: Merged FTIR spectrum of four brands metronidazole injections and metronidazole ICRS.

\section{Weight uniformity test result}

Weight uniformity test was done using a method specified in USP 2015. According to USP 2015 specification, the requirements for dosage uniformity are met if the acceptance value (AV) of the first 10 dosage units is less than or equal to L1\%, which 15(22). Weight uniformity test result of Metronidazole capsule brands is shown in table 3 . Thus, according to the results, all the three brands of Metronidazole capsules passed a weight uniformity test.

Table 3: Weight uniformity test result of randomly selected Metronidazole capsules $(n=10)$.

\begin{tabular}{|l|l|l|l|l|l|l|}
\hline Brand Name & $\begin{array}{l}\text { av.xi } \\
(\%)\end{array}$ & sd & $\%$ RSD & $\begin{array}{l}\text { M } \\
(\%)\end{array}$ & $\begin{array}{l}\text { Acceptance } \\
\text { value }\end{array}$ & $\begin{array}{l}\text { USP 2015 } \\
\text { limit }\end{array}$ \\
\hline Metronidazole(Generic) & 107.55 & 1.32 & 1.23 & 101.5 & 9.218 & L1<15 \\
\hline Camezol & 102.71 & 2.63 & 2.56 & 101.5 & 7.522 & L1<15 \\
\hline Metazol & 104.04 & 2.2 & 2.12 & 101.5 & 7.82 & L1<15 \\
\hline
\end{tabular}

\section{Dissolution test result}

The dissolution test for the Metronidazole capsules was performed using a method specified in USP 2015, in which it is indicated that the $85 \%$ of the active ingredient should be released in 30 minutes(22). In the current study, all the three brands of Metronidazole capsules studied released more than $85 \%$ of API within 30 minutes. Statistical comparison of dissolution (release of API) at $95 \%$ confidence interval revealed that there exists significant difference in drug release within and among the three brands of Metronidazole capsules $(\mathrm{p}<0.05)$. The percentage of dissolution of the brands is shown below.

Table 4: Result of time dependent dissolution of three brands of Metronidazole capsules ( $n=6)$.

\begin{tabular}{|l|l|l|l|}
\hline $\begin{array}{l}\text { Sampling } \\
(\mathrm{min})\end{array}$ & time & \multicolumn{3}{l|}{$\%$ drug released (mean $\pm \mathrm{RSD} ; \mathrm{n}=6)$} \\
\cline { 2 - 4 } & Metronidazole & Metazol & Camezol \\
\hline
\end{tabular}




\begin{tabular}{|l|l|l|l|}
\hline & (generic) & & \\
\hline 10 & $93.68 \pm 2.25$ & $94.55 \pm 2.55$ & $100.67 \pm 1.11$ \\
\hline 15 & $97.23 \pm 1.04$ & $98.47 \pm 1.3$ & $102.04 \pm 1.18$ \\
\hline 20 & $98.26 \pm 1.19$ & $100.96 \pm 0.97$ & $103.76 \pm 1.16$ \\
\hline 30 & $99.71 \pm 1.19$ & $101.76 \pm 1$ & $106.61 \pm 1.16$ \\
\hline 45 & $100.1 \pm 1.507$ & $101.86 \pm 0.64$ & $106.86 \pm 1.4$ \\
\hline 60 & $99.81 \pm 0.788$ & $102.80 \pm 1.41$ & $106.69 \pm 1.51$ \\
\hline
\end{tabular}

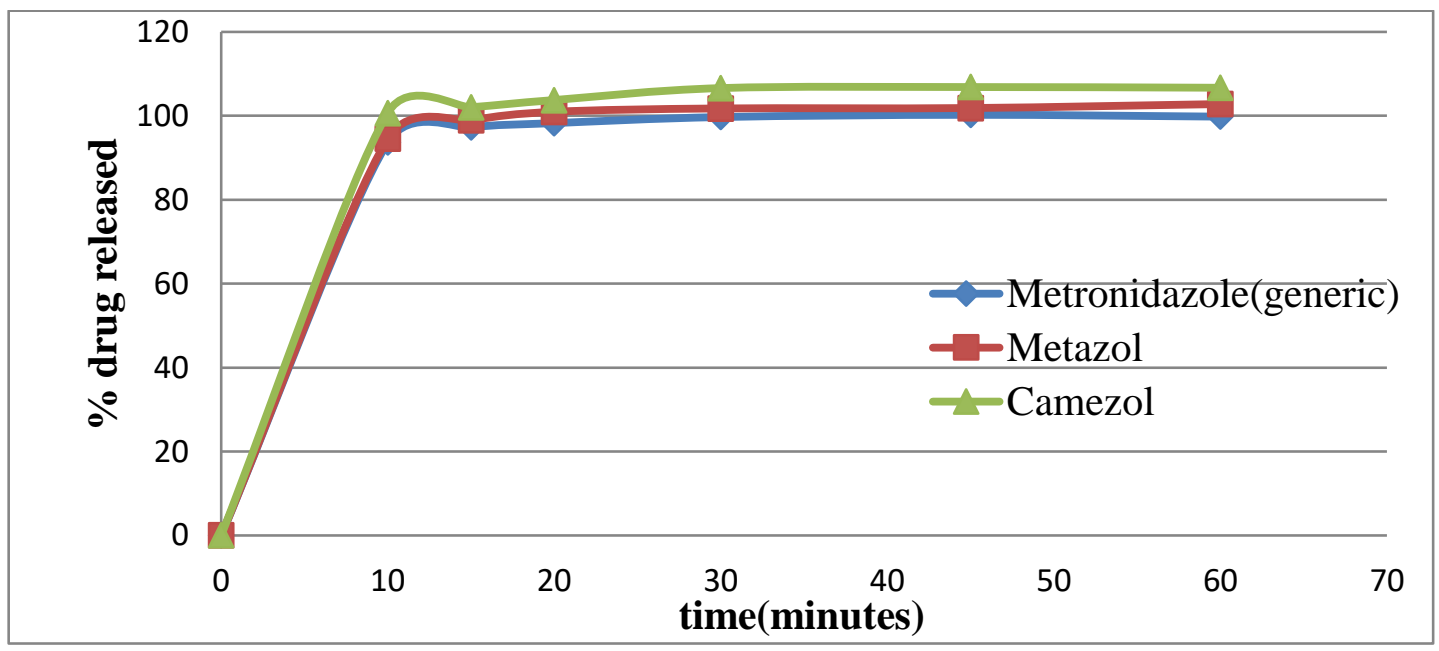

Figure 4: Time dependent dissolution profile of three brands of metronidazole capsules.

\section{Assay test result}

For drugs to be therapeutically effective, the formulation ought to contain the API in officially approved extent that produces desired therapeutic effect. All the seven brands of Metronidazole studied passed USP 2015 specification for assay of the product (Table 5). Statistical comparison of drug contents at $95 \%$ confidence interval indicates that there exists significant difference in drug content within and among the all the seven brands of Metronidazole $(\mathrm{p}<0.05)$. In discrepancy with this study result, failure to comply with assay specification limit was reported in similar in-vitro quality assessment studies conducted on the drug in Eastern Nigeria(16), Myanmar (25), Bangladesh (26) and China (27), where 3 from 10 brands of Metronidazole tablets, 1 from 14 Metronidazole tablets, 6 from 40 
brands of Metronidazole and 41 from 108 Metronidazole failed assay test in the respective studies. The cause for the products to fail assay test on the studies may be the drugs analyzed on respective studies are counterfeited.
Substandard quality Metronidazole induces drug resistance, which in turn causes deleterious negative impacts such as increased morbidity, mortality, treatment cost, hospital stay days and others.

Table 5: Assay result of Metronidazole capsules and Metronidazole injections ( $n=3)$.

\begin{tabular}{|l|l|l|l|l|}
\hline \multirow{2}{*}{ Product } & Brand Name & $\begin{array}{l}\text { Assay result } \\
(\%)\end{array}$ & $\pm \mathrm{RSD}(\%)$ & USP 2015 limit \\
\hline \multirow{3}{*}{$\begin{array}{l}\text { Metronidazole } \\
\text { Capsule }\end{array}$} & Metronidazole(Generic) & 107.81 & 0.113 & $90-110 \%$ \\
\cline { 2 - 5 } & Camezol & 102.96 & 0.229 & $90-110 \%$ \\
\cline { 2 - 5 } & Metazol & 104.34 & 0.138 & $90-110 \%$ \\
\hline \multirow{3}{*}{$\begin{array}{l}\text { Metronidazole } \\
\text { Injection }\end{array}$} & Aldezol & 96.98 & 0.018 & $90-110 \%$ \\
\cline { 2 - 5 } & Metrogyl & 99.63 & 0.003 & $90-110 \%$ \\
\cline { 2 - 5 } & Metris & 100.3 & 0.021 & $90-110 \%$ \\
\cline { 2 - 5 } & Nirmet & 101.03 & 0.009 & $90-110 \%$ \\
\hline
\end{tabular}


Microbiological quality tests of Metronidazole Injections

\section{Sterility test result}

Sterility test result of the samples is indicated in table 6. The samples were analyzed for sterility as per a method indicated in USP 2015(22). Two brands (i.e. Aldezol and Metris), failed sterility test from the four brands of Metronidazole injections included in the study and hence of poor quality. Microbiological quality of the liquid dosage forms should be maintained in official specifications limit throughout the shelf life of the drug for the dosage form to be stable and therapeutically effective.
Microbial contamination liquid dosage preparations cause spoilage of the product which results in degradation and instability of the product. Subsequent treatment of patients who are already immunecompromised with such microbiologically contaminated products causes increased morbidity and mortality $(28,29,30)$

\section{LAL test result}

The products were tested for bacterial Endotoxin test according to a method specified in USP 2015(22). LAL test result of Metronidazole injections is shown in table7. As indicated on the table, all the four brands of Metronidazole injections passed a test for Endotoxin.

Table 6: Sterility test result of Metronidazole injections ( $\mathrm{n}=1$ ).

\begin{tabular}{|c|c|c|c|c|c|c|c|c|c|c|c|c|c|c|}
\hline \multirow{2}{*}{$\begin{array}{l}\text { Product } \\
\text { name }\end{array}$} & \multicolumn{14}{|c|}{ Days } \\
\hline & 1 & 2 & 3 & 4 & 5 & 6 & 7 & 8 & 9 & 10 & 11 & 12 & 13 & 14 \\
\hline Aldezol & -ve & -ve & -ve & -ve & -ve & $-\mathrm{ve}$ & $+\mathrm{ve}$ & $+\mathrm{ve}$ & $+\mathrm{ve}$ & $+\mathrm{ve}$ & $+\mathrm{ve}$ & $+\mathrm{ve}$ & $+\mathrm{ve}$ & $+\mathrm{ve}$ \\
\hline Metris & -ve & -ve & -ve & -ve & -ve & $-\mathrm{ve}$ & -ve & -ve & $-\mathrm{ve}$ & $+\mathrm{ve}$ & $+\mathrm{ve}$ & $+\mathrm{ve}$ & $+\mathrm{ve}$ & $+\mathrm{ve}$ \\
\hline $\begin{array}{l}\text { Metrogy } \\
1\end{array}$ & -ve & -ve & -ve & -ve & -ve & $-\mathrm{ve}$ & -ve & -ve & -ve & -ve & -ve & -ve & -ve & -ve \\
\hline Nirmet & -ve & -ve & -ve & -ve & -ve & -ve & -ve & -ve & -ve & -ve & -ve & -ve & -ve & -ve \\
\hline
\end{tabular}

Table 7: LAL test result of Metronidazole injections $(\mathrm{n}=1)$.

\begin{tabular}{|l|l|l|}
\hline Brand name & Endotoxin concentration & USP 2015 limit \\
\hline Aldezol & $<0.25 \mathrm{Eu} / \mathrm{ml}$ & $<0.35 \mathrm{Eu} / \mathrm{ml}$ \\
\hline Metris & $<0.25 \mathrm{Eu} / \mathrm{ml}$ & $<0.35 \mathrm{Eu} / \mathrm{ml}$ \\
\hline
\end{tabular}




\begin{tabular}{|l|l|l|}
\hline Metrogyl & $<0.25 \mathrm{Eu} / \mathrm{ml}$ & $<0.35 \mathrm{Eu} / \mathrm{ml}$ \\
\hline Nirmet & $<0.25 \mathrm{Eu} / \mathrm{ml}$ & $<0.35 \mathrm{Eu} / \mathrm{ml}$ \\
\hline
\end{tabular}

Conclusion: The result of the current study revealed that there was incidence of poor quality Metronidazole in Jimma town. Therefore, post marketing quality assessment should be performed routinely to determine quality status of the drug on market.

\section{Limitation of the study}

Since this study is based upon convenience sampling, the result of the study may not indicate exact quality status of the drug in the study area.

\section{Acknowledgement}

The author acknowledges Jimma University School of Pharmacy and Ethiopian pharmaceuticals manufacturing company (EPHARM) for permitting to use their laboratory and freely giving metronidazole standard.

\section{Declarations}

Consent to publish: Not applicable
Funding: Jimma University

Competing interests: The authors declare that they have no competing interests.

Author's contribution: Author TS involved in the conception and design of the study, participated in the literature searches, analyzed data and wrote the manuscript. All the authors approved the final manuscript. Author TM involved in the conception and design of the study, participated in the literature searches, supervised data collection and analyzed data. Author RT participated in the design of the study, supervised data collection and the overall research, and commented the manuscript.

\section{Availability of data and materials:} The supporting documents for this study can be available from the corresponding author upon request.

\section{Abbreviations}

BP: British Pharmacopeia

USP: United States Pharmacopeia

WHO: World Health organization 


\section{References}

1. WHO. WHO global surveillance and monitoring system for substandard and falsified medical products, Geneva, Switzerland. 2017.

2. Almuzaini, T., Choonara, I \& Sammons, H. 2013. Substandard and counterfeit medicines: a systematic review of the literature. BMJ. 2013; 3:e002923.

3. Kelesides, T., Kelesides, I., Rafailidis, I \& Falagas, M.E. Counterfeit or substandard antimicrobial drugs: a review of scientific evidence. Journal of antimicrobial chemotherapy. 2007; 60: 214-236.

4. Kelesidis, $\mathrm{T} \&$ Falagas, E. Substandard/counterfeit antimicrobial drugs. Clinical microbiology reviews. 2015; 28(2): 443-464.

5. Alghannam, A.F.A., Aslanpour, Z., Evans, S \& Schifano, F. A systematic review of counterfeit and substandard medicines in field quality surveys. Integrated pharmacy research. 2014; 3: $71-88$.

6. Sammons, H.M \& Choonara, I.
Substandard medicines: a greater problem than counterfeit medicines? BMJ Paediatrics Open. 2017; m1:e000007.

7. Seither A. Health and economic consequences of poor quality medicines. Clinical pharmacology and therapeutics. 2009; 4(5): 476-478.

8. Newton, P.N., Green, M.D \& Ferna'ndez, F.N. Impact of poorquality medicines in the developing' world. Trends in pharmacological sciences. 2009; 31(3): 99-101.

9. Alhedethe, A., Alhudaithy, K \& Zloh, M. An evaluation of prevalence of low quality of medicines in Saudi Arabia and factors associated an analytical comparative study. Archives in chemical research. 2017; 1(3): 1-18.

10. Wilson, J. M. The health and economic effects of counterfeit pharmaceuticals in Africa. 2011. Available at: http://www.acappp.msu.edu/ index.html. Accessed at $9 / 21 / 17$.

11. Rediguieri, C F., Porta, V., Nunes, G., Diana, S., Nunes, T. M \& Junginger, H. E., et al. Biowaiver monographs for immediate release 
solid oral dosage forms: Metronidazole. Journal of pharmaceutical sciences. 2011; 100 (5): 1618-1627.

12. Hedge, D.D., Strain, J.D., Heins, J.R \& Farver D.K. New advances in the treatment of clostridium diffi cile infection (CDI). Therapeutics and clinical risk management. 2008; 4(5): 949-964.

13. Peedikayil, F.C. Antibiotics in odontogenic Infections - An update. J Antimicro. 2016; 2(2): 1-4.

14. Dhand, A \& Snydman, D. R. Mechanism of resistance in metronidazole mechanism of resistance in metronidazole. 2014. doi: 10.1007/978-1-59745-180-2.

15. Taylor, R.B., Shakoor, O., Behren, R.H., Everard, M., Low, A.S \& Wangboonskul, $\mathrm{J}$ et al. Pharmacopoeial quality of drugs supplied by Nigerian pharmacies. Lancet. 2001; 357: 1933-36.

16. Ibezim, E.C., Attama, A.A., Obitte, N.C., Onyishi, V.I \& Brown, S.A. In vitro prediction of in vivo bioavailability and bioequivalence of brands of metronidazole tablets in Eastern Nigerian drug market. Scientific research and essay. 2008; 3(11): 552-558.
17. Tschida, S. A Systematic Review on Antibiotic Quality. Master of phlosophy thesis, dept.of community Health,Oslo University.pp. 18. 2016.

18. Rasoloson, D., Vanacova, S., Tomkova, E., Razga, I., Hrdy, I \& Tachezy, $\mathbf{J}$ et al. Mechanisms of in vitro development of resistance to metronidazole in Trichomonas vaginalis. Microbiology. 2002; 148(8): 2467-2477

19. Van der Wouden, E.J., Van Zwet, A.A., Thijs, J.C, Vosmaer, G.D.C., Oom , J.A.J \& De Jong, A et al. Rapid increase in the prevalence of helicobacter pylori in the Netherlands. Emerging infectious diseases. 1997; 3(3): 386-387

20. WHO. Guidelines on the conduct of surveys of the quality of medicines, Geneva, Switzerland, 2015.

21. United States Pharmacopoeia. The United States Pharmacopoeial convention, Rockville, Volume III. 2015.

22. British Pharmacopoeia. The Stationery Office, London, Volume III. 2013.

23 Kahaliw, W \& Ashenef, A. Comparative quality evaluation of 
some metronidazole tablets and metronidazole benzoate oral suspension available in retail outlets of Addis Ababa, Ethiopia. Int J Pharm Sci Res. 2013; 4(4): 1384-1391.

24. Musa, H., Sule, Y.Z \& Gwarzo, M.S. Assessment of physicochemical properties of metronidazole marketed in Zaria, Nigeria. International journal of pharmacy and pharmaceutical sciences. 2011; 3(3): 27-29.

25. WHO. Counterfeit and substandard drugs in Myanmar and Viet Nam, Geneva, pp. 18-19.1999.

26. Ahmed, F., Das, A.k., Karmakar, U.K., Khaleque, T.K \& Shill, M.C. Quality of marketed metronidazole preparations in Bangladesh-an analytical overview. Journal of biological sciences. 2003; 3(10): 940950.
27. Pan, H., Luo, H., Chen, S \& BaThein, W. Pharmacopoeial quality of antimicrobial drugs in southern China. Lancet global health. 2013; 4(5): 300302.

28. Amrutha, A.V., Gangadharappa, H.V., Kiran, H.C \& Shuchithra, S. Inprocess and finished products quality control tests for sterile and non sterile dosage form. Int. J. Pharm. Sci. Rev. Res. 2017; 45(1): 206-214.

29. Mwambete, K. D., Justin-temu, M \& Fazleabbas, F.S. Microbiological assessment of commercially available quinine syrup and water for injections in Dar Es Saalam, Tanazania. Tropical journal of pharmaceutical research. 2009; 8(5): 441-447.

30. Hasegawa, T., Takagi, K \& Kitaichi, K. Effects of bacterial endotoxin on drug pharmacokinetics. J.med.Sci. 1999; 62: 11-28 